\title{
A PHARMACOGNOSTIC AND PHARMACOLOGICAL REVIEW ON CANNA INDICA LINN
}

\author{
Shrinivas K Sarje*, Kushewati Ingole, Shinde Angad, \\ Bhutnar Priya and Nitin B Ghiware \\ Department of Pharmacology, Nanded Pharmacy College, \\ Nanded, Maharashtra, India.
}

\begin{abstract}
Canna indica $L$. is a tropical herb belonging to family Cannaceae. It has been widely used in traditional medicine for the treatment of many complains. The phytochemical analysis of Canna indica showed that it contained various phytochemicals including flavonoids, carbohydrates, terpenoids, alkaloids, proteins, steroids, cardiac glycosides, oils, saponins, tannins, anthocyanin pigments, phlobatinins \& many other chemical compounds. The pharmacological studies showed that Canna indica plant exerted antiviral anthelmintic, anti-inflammatory, antibacterial, antioxidant, molluscicidal, cytotoxic, hepatoprotective, analgesic immunmodulatory, hemostatic, anti-diarrheal and other effects. This article aims to provide information which is required to claim \& explore its pharmacognostic\& pharmacological profile. Every part of Canna has beneficial properties that can serve humanity so the whole plant can be extensively studied for further research aspects.
\end{abstract}

Keywords: Canna indica, Constituents, Pharmacology, Antioxidant Activity and Hepatoprotectives.

\section{INTRODUCTION}

Healing with medicinal plant is as old as mankind itself. The connection between man and his search for drugs in nature dates from the far past. As a result of accumulated experience from the past generation, today, all the world's cultures have an extensive knowledge of herbal medicine. The previous treatment was not based on a true scientific knowledge. However, in the early nineteenth century, many sensitive ingredients were isolated \& introduced in the medical practice (Al-Snafi AE. 2015). Canna indica $L$. commonly known as an Indian shot, the Canna arises from the Greek word for a cane or reed. Canna is the only genus in the family Cannaceae\& 19 species of flowering plants. The species have large, eye-catching foliage \& horticulturists have turned it into a largeflowered \& bright garden plant. In addition, it is a horticultural plant \& is one of the world's richest starch sources. It extensively used as a nutritive agent \& has a number of valuable pharmacological activities (Kessler JR. 2007).

\section{PLANT PROFILE synonyms}

Canna coccinea Mill, Canna edulis Ker-Gawl, Canna lutea Mill, Canna achiras Gilles (VanitaKanase et al., 2018).

Botanical Classification (Tanaka N. 2001)
\begin{tabular}{|c|c|}
\hline Kingdom & Plantae \\
\hline Subkingdom & Tracheobiont \\
\hline Superdivision & Spermatophyta \\
\hline Division & Magnoliophyta \\
\hline Class & Liliopsida \\
\hline Subclass & Zingiberidae \\
\hline Order & Zingiberales \\
\hline Family & Cannaceae \\
\hline Genus & Canna \\
\hline Species & Indica $L$. \\
\hline
\end{tabular}


Vernacular Names (Mishra S et al., 2013)

\begin{tabular}{|c|c|}
\hline Languages & Names \\
\hline English & $\begin{array}{c}\text { African arrowroot, Canna lily, } \\
\text { Canna Indian shot, Wild } \\
\text { canna }\end{array}$ \\
\hline Hindi & Sarvajjaya, SakaSiri, Devkali \\
\hline Marathi & Kardal \\
\hline Sanskrit & Vankelee, Devakuli \\
\hline Spanish & Chupaflor \\
\hline Andes & Achira \\
\hline French & Balisier comestible \\
\hline Tamil & Puvalaikalvalai \\
\hline Arabic name & $\begin{array}{c}\text { Canna Hindi, Muzwardi, } \\
\text { \&Muzfahal }\end{array}$ \\
\hline Telugu & Krishna Tamara \\
\hline Konkani & KelePhool \\
\hline Manipuri & Laphoorit \\
\hline Kannada & Kalahu \\
\hline Bengali & Sarbajaya, Kalaboti \\
\hline
\end{tabular}

\section{Origin}

The first species of Canna introduced to Europe was Canna indica L, Which was imported from the East Indies, though the species originated from the America. Charles de Ecluse, who first described \& sketched Canna indica indicates this origin, \& states that it was given the name of indica (Indrayan,A.K., et al., 2011). Much later, in 1658, Pison made reference to another species which he documented under the vulgar or common name of 'Albara' \& 'Pacivira', which resided, he said, in the shaded \& damp places, between the tropics, this species is Canna angustifolia L.(de 1'Ecluse, Charles 1576).

Without exception, all Canna species that have been introduced into Europe can be traced back to the America, \& it can be asserted with confidence that Canna is solely an American genus. If Asia \& Africa provided some of the early introductions, they were only varieties resulting from Canna indica \& Cannaglauca cultivars that have been grown for a long time in India\& Africa, with both species imported from Central \& South America. Canna is an American genus, as pointed out by Lamarck (pison 1658) where he argues that "Cannas were unknown to the ancients, \& that it is only after the discovery of the New World, that they made their appearance in Europe'. Since Cannas have very hard \& durable seed coverings,(Tanaka, N. 2001) (Lamarck, JeanBaptiste.) it is likely that seed remains would have survived in the right condition \& been found by archaeologists in the Old World. If the soils of India or Africa had produced some of them, they would have been imported before the 1860s into European gardens (Grootjen, C. J. et al,. 1988).

\section{Habitat and Geographical Distribution}

The Canna genus is native tropical \& subtropical regions of Southern United State \& South to Northern Argentina \& Philippines in settled areas, occurring in waste places \& near tikas Canna settlements (Lerman, J. C. et al., 1971). In America wild species grow in the South of the United States, South America, from Venezuela to Argentina \& India. Terrestrial plants usually live in tropical \&subtropical rain forests, montane, premontane\& gallery forests. Palustrine plants grow in forest edges, wetlands, marshes \& riversides. Many taxa are nitrophilous\& mostly found in humid loose soils, near streams, in uncultivated public lands or on road sides. The plant prefers light (sandy), medium (loamy) \& heavy (clay) soils \& requires well-drained soil. The plant prefers acid, neutral \& basic (alkaline) soils. It cannot grow in the shade. It requires moist soil (Chate, E. (1867). (Enrique J. Baranl et al., (2010).

\section{Culture \\ Light}

Grow Canna indica in full sun to partial shade. It will benefit from some midday shade in hot climates.

\section{Moisture}

Indian shot grows best in a moisture retentive soil. Water freely when in bloom.

\section{Hardiness}

Where not hardy, Indian shot can be lifted \& brought indoors for winter. When the leaves come blackened from the first good frost, cut off the stems \& leaves \& dig up the rhizomes for winter storage in damp peat or sawdust.

\section{Propagation}

Propagation of Canna can be done by seeds or root cuttings. The seeds are small, globular, black pellets, hard \& heavy enough to sink in water. They resemble shotgun pellets giving rise to the plant's common name of Indian shot. Allow seed heads to dry on plants then remove them \& collect the seeds. Cannas are grown in borders \& beds, \& are among the most popular flowers in tropical \& subtropical gardens. Where not hardy, rhizomes can be planted out in spring for summer blooming, then dug in autumn for winter storage. Indian shot also can be grown in containers. To propagate plants by seeds, pre-soak them for 24 hours in warm water \& sow them in late winter to early spring, in a warm greenhouse or indoors at $20^{\circ} \mathrm{C}(68 \mathrm{~F})$. Sow seeds $2-5 \mathrm{~cm}$ deep in individual post. Scarifying the seeds can speed germination, especially if the seeds have not swollen after being soaked. The seeds usually germinate in 3-9 weeks. Grow the plants on in a greenhouse for at least their first winter. Plant them out into their permanent positions in late spring or early summer, after 
the last expected frosts. To propagate Canna by root cuttings, divide root clump as the plant comes into growth in the spring. Each portion must have at least one growing point. Pot up the division \& grow them on in the greenhouse until they are well established \& then plant them out in the summer in their permanent position. Avoid planting out young plants until all risk of frost has passed as the frost may damage the new growths. Water regularly during the growing season, avoid letting them dry out between watering \& apply a phosphorus-rich liquid fertilizer each month for optimum results (Indira Priya Darsini A et al., 2015).

\section{Ecology and Pollination Biology}

Cannas are found scattered in transitional habitats, both natural \& artificial. In the wild they grow along the edges of marshes \& forest margins, often in water up to $10 \mathrm{~cm}$ deep. They also thrive in spoil banks, roadside ditches \& refuse sites given adequate moisture \& seasonal drought. Seeds germinate \& produce reproductive shoots in a single growing season ( less than 4 months), generally flowering mid to late rainy season. Some studies indicatesthese flowers might be pollinated by hawk moths. However, pollen is shed before the flowers open, resulting in selfpollination. Indeed, greenhouse grown plants set seed readily, even in the absence of any likely pollinator. The coloration \& floral tube of some suggest hummingbird pollination (Kubitzki, 1998).

Varieties of Canna species

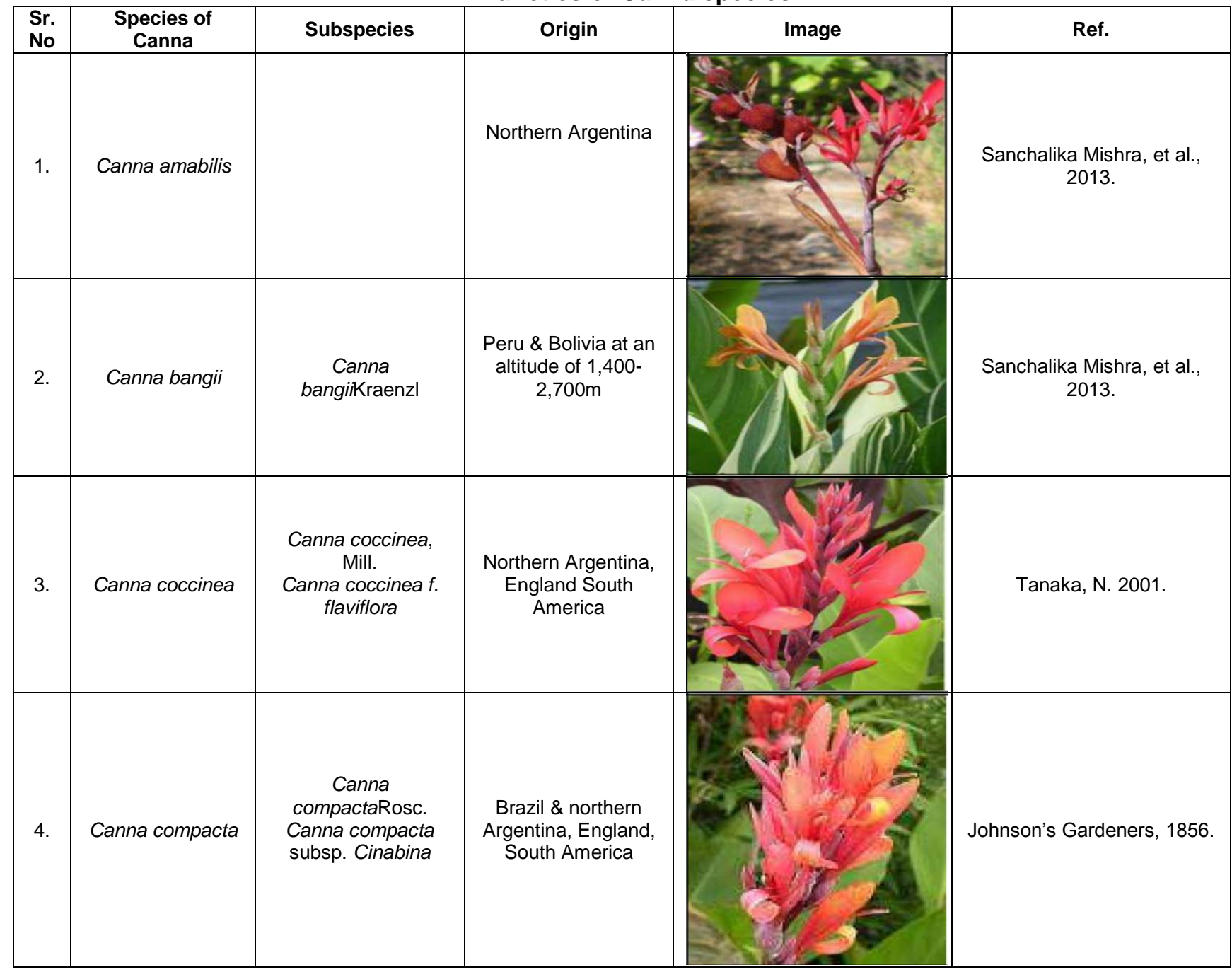




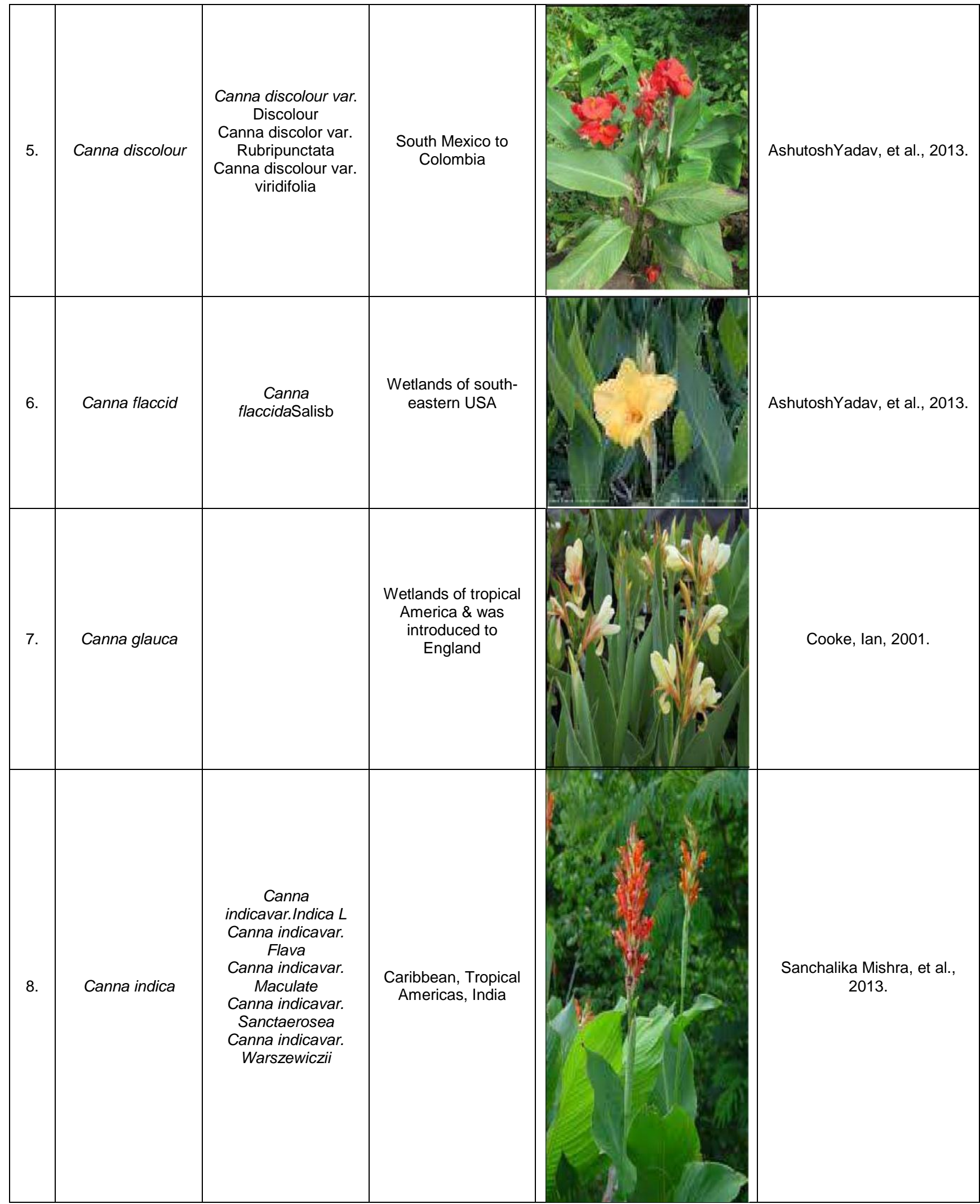




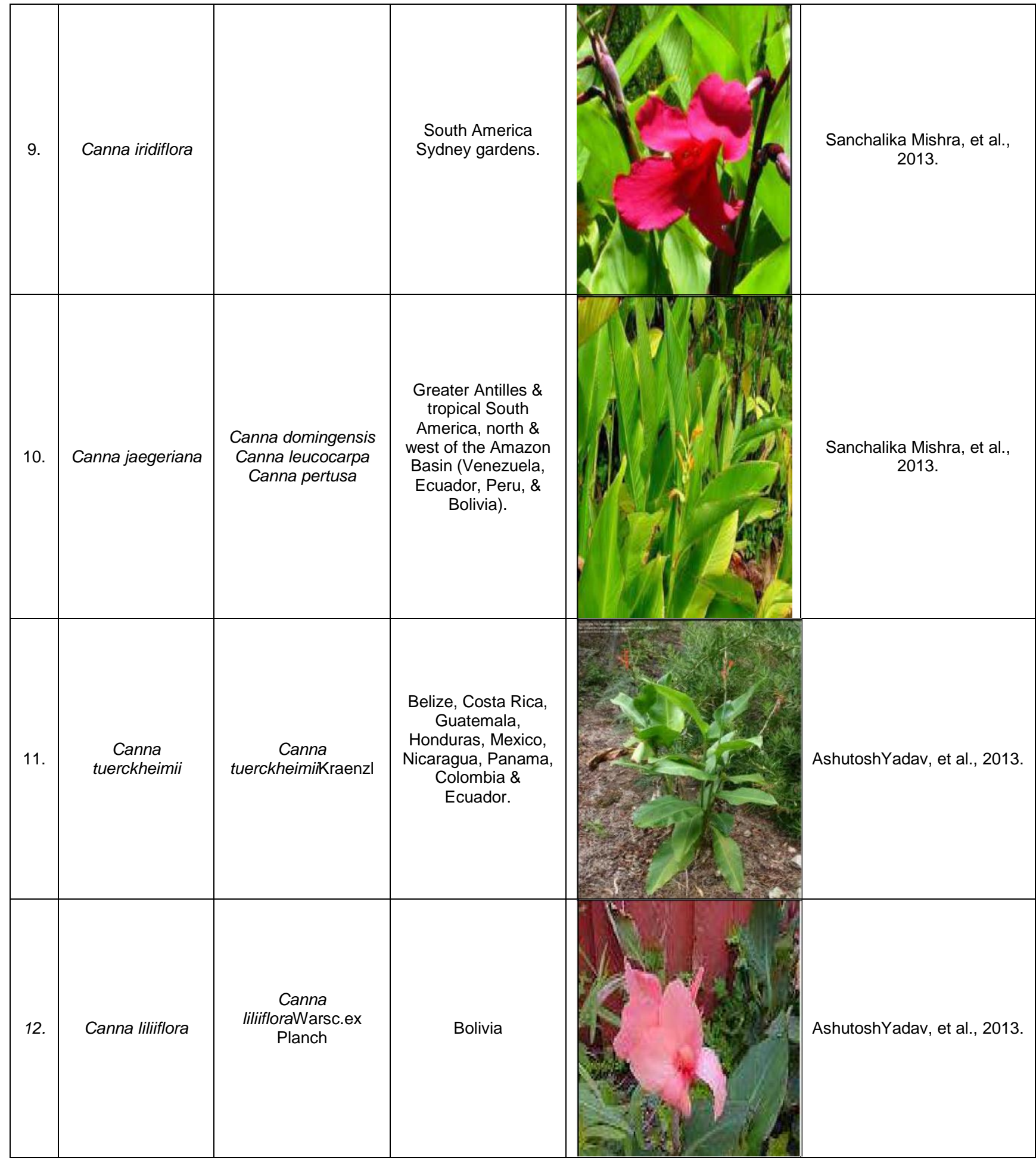




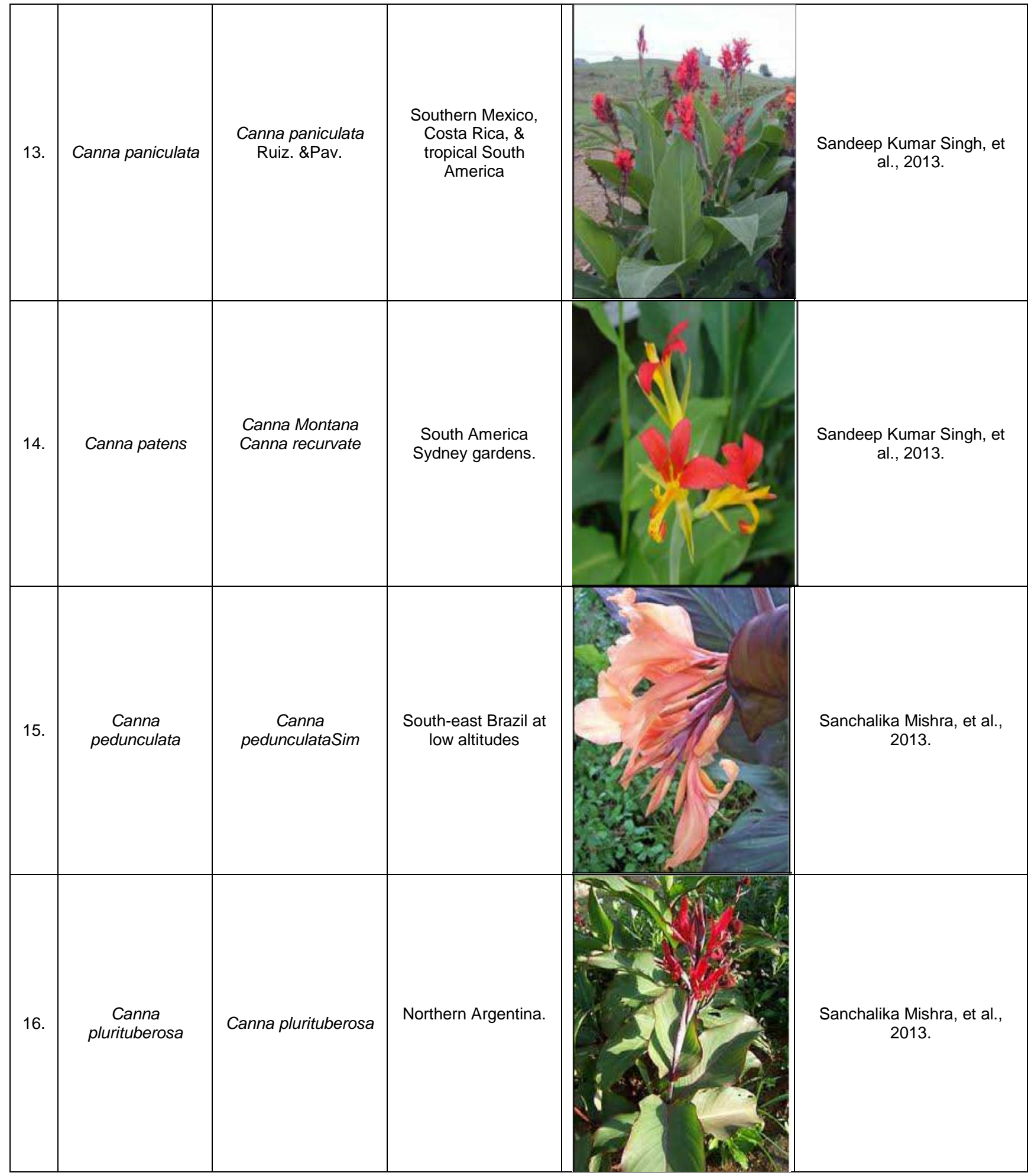




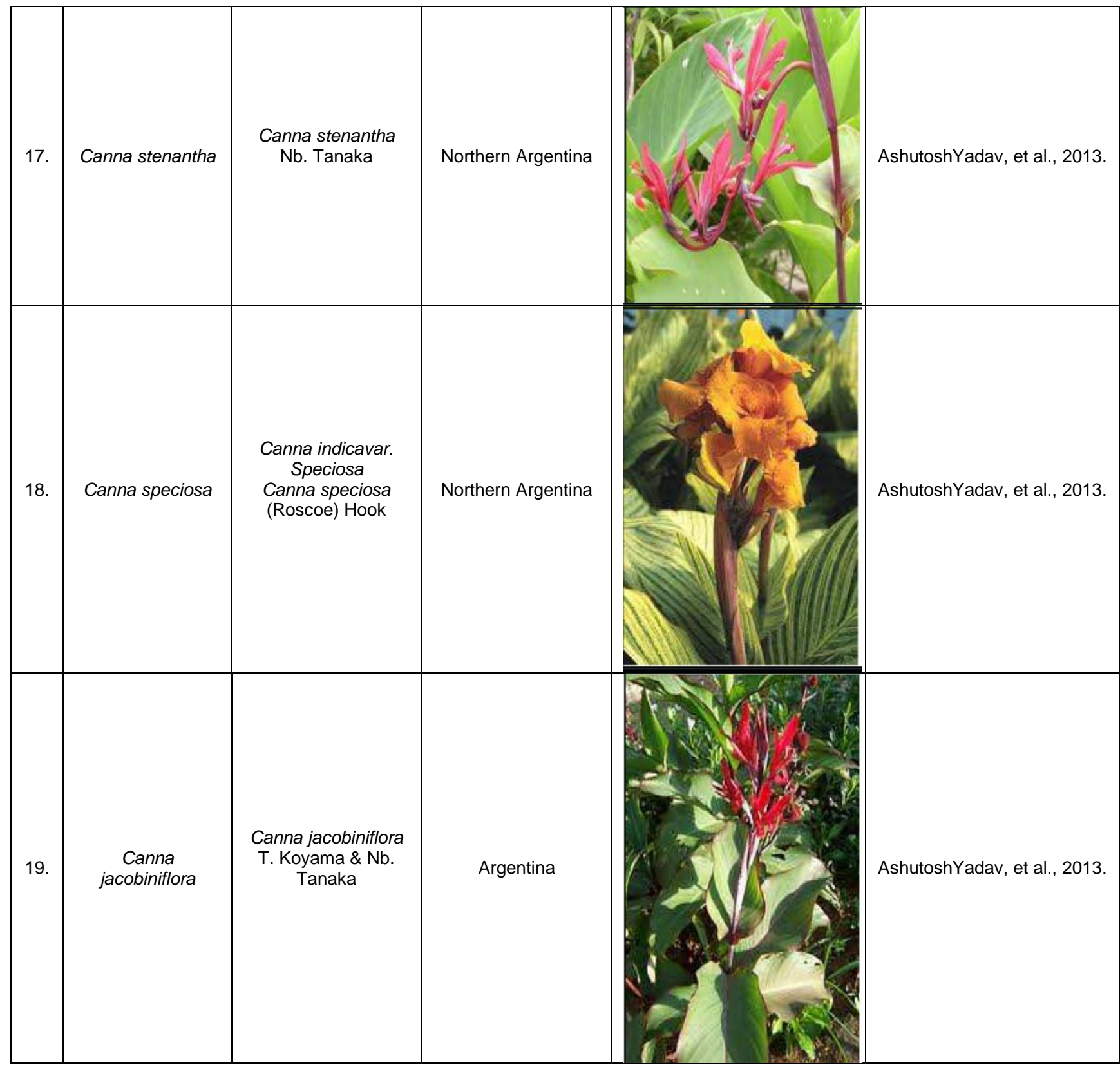


Pharmacognostical Studies of Canna Species

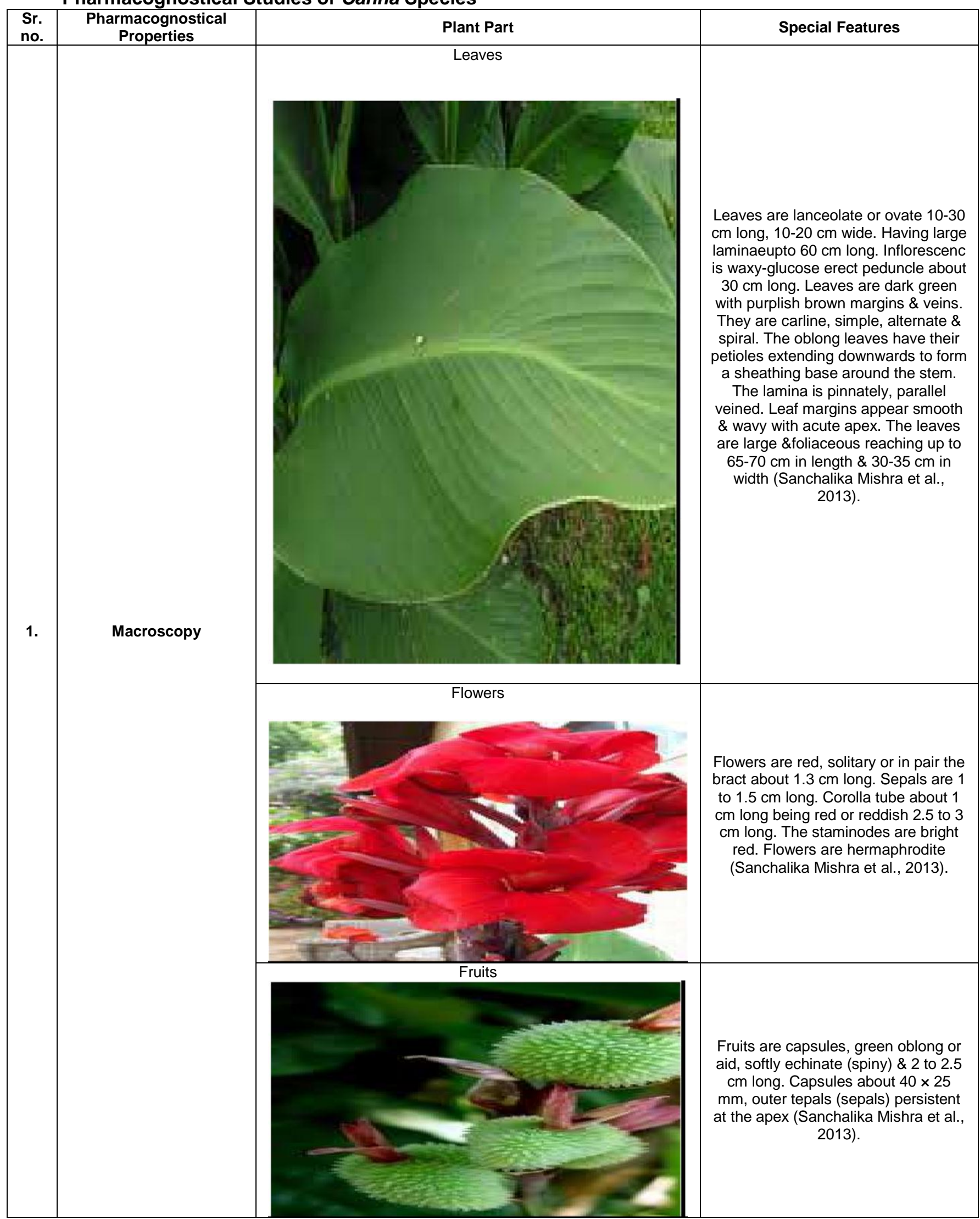




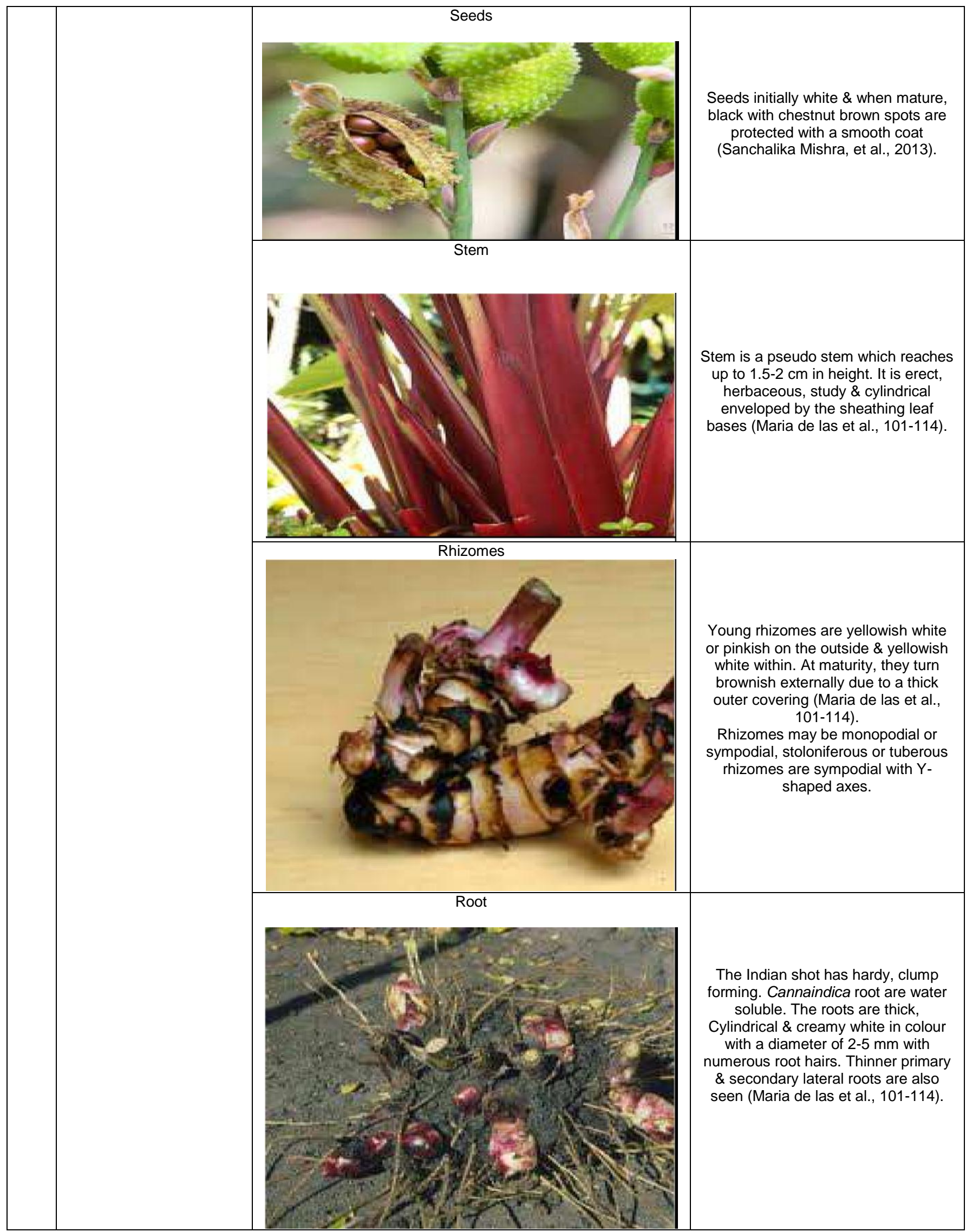




\begin{tabular}{|c|c|c|c|}
\hline \multirow{4}{*}{2.} & \multirow{4}{*}{ Microscopy } & Leaves & $\begin{array}{l}\text { Leaf is typical of a monocot. A single } \\
\text { layered epidermis made up of } \\
\text { rectangular cells occurs is a few } \\
\text { layers of parenchyma cells followed } \\
\text { by a few layers of chlorenchyma, } \\
\text { Sclerenchyma patches occur on } \\
\text { either side of the vascular bundle. } \\
\text { The leaves are amphistomatic. } \\
\text { Stomatal density-2 mm. }\end{array}$ \\
\hline & & Seeds & $\begin{array}{l}\text { Seed microstructure consists of a } \\
\text { massive chalaza, surrounded by an } \\
\text { extremely hard, completely } \\
\text { impermeable seed coat. The } \\
\text { epidermis is composed by a palisade } \\
\text { layer of long \& narrow cells with very } \\
\text { thickened walls called Malphigian } \\
\text { cells. Integumentary tissue: The area } \\
\text { around the inner integument. The } \\
\text { integumentary seed coat is similarly } \\
\text { composed of } 4 \text { layers: epidermis or } \\
\text { palisade layer, subepidermal, } \\
\text { vascularized, \&tanniferous layer. }\end{array}$ \\
\hline & & Stem & $\begin{array}{l}\text { The uniseriate epidermis is followed } \\
\text { by an undifferentiated ground tissue. } \\
\text { Two to three layers of regularly } \\
\text { arranged parenchyma cells occur } \\
\text { below the epidermis. This is followed } \\
\text { by } 2-3 \text { layers of chlorenchymatous } \\
\text { tissue that formed a band. A few U- } \\
\text { shaped sclerenchymatous patches } \\
\text { occur at regular intervals below \& in } \\
\text { contact with the } \\
\text { chlorenchymatousvascular bundles } \\
\text { scattered throughout the ground } \\
\text { tissue. Each vascular bundle is } \\
\text { conjoint, collateral, end arch \& closed. }\end{array}$ \\
\hline & & Rhizomes & $\begin{array}{l}\text { The epidermis cell walls are scarcely } \\
\text { cutinized. Beneath the epidermis } \\
\text { there is a three layered hypodermis, } \\
\text { which exhibits cells with sub } \\
\text { polygonal outline \& thickened walls. } \\
\text { The cortex is a relatively thin zone } \\
\text { placed between the hypodermis \& the } \\
\text { endodermis. It is mainly composed by } \\
\text { a parenchymatous tissue (Sanchalika } \\
\text { Mishra et al., 2013). }\end{array}$ \\
\hline 3. & $\begin{array}{c}\text { Detection of } \\
\text { compounds through } \\
\text { thin layer } \\
\text { chromatography }\end{array}$ & Rhizomes & $\begin{array}{l}\text { The bioactive fractions of Canna } \\
\text { indica rhizomes extract were } \\
\text { analysed through thin layer } \\
\text { chromatography (TLC) using the } \\
\text { method of Wagner \&Bladt, } 1996 \text {. } \\
\text { About } 10 \mu \text { of extract ( } 2 \mathrm{mg} / \mathrm{ml} \text { ) of all } \\
\text { the bioactive fractions were loaded on } \\
\text { TLC plates. The plate was air dried \& } \\
\text { developed in Hexane: Diethyl ether } \\
\text { (2:3) for } 30 \text { min. The plate was dried } \\
\left.\text { in a hot oven (at } 80{ }^{\circ} \mathrm{C} \text { for } 10 \mathrm{~min}\right) \& \\
\text { detected under UV light ( } 365 \mathrm{~nm}) \& \\
\text { ammonia vapour. For spraying iodine } \\
\text { solution, Natural } \\
\text { Product/Polyethylene Glycol reagent } \\
\text { (5\% NP/PEG in ethanolic solution), } \\
\text { Ferric chloride (1\% solution in } 50 \% \\
\text { aqueous methanol) were used in the } \\
\text { experiment (Maria de las et al., } 101- \\
\text { 114). }\end{array}$ \\
\hline
\end{tabular}




\section{Phytoconstituents of Canna indica \\ Root}

Root contains the chemical constituent's cannagenins. Rootstock contains enzymes, triacontanal\& mixture of stigmasterol, $\beta$ sitosterol, campesterol\& $\beta$ lectin\& traces of alkpiels (Jayakumari T. R. et al., 164-168).

\section{Rhizomes}

Rhizomes yield fat, traces of an alkaloid, gum \& starch. Phytochemical screening yielded phenols, sterols, flavonoids\&saponins. Composition of the unsaponifiable matter from Canna indica rhizome are 5,8Henicosdiene, 7Henicosyne, 3, 15- Dihydroxy-2-octadecene, 6- Hydroxyeicosane, Tricosane, Tetracosane (Tripathi S.M. et al.,2000).

\section{Leaves}

The major constituents normally occur in Canna leaf extract sucrose, amino acids, organic acids, citric, malic, glyceric, succinic, \& lactic acids, \& the aspartic, glutamic, glutamine, \& alanine. Leaves also contains lignin, furfural, hemicelluloses (Ghani, A. 2003).

\section{Flowers}

The flowers of Canna indica are brightly red. The appearance of red colour is due to presence of flavonoids, phenols \&anthocyanins. Flowers contain lutein, $\beta$ carotene, violxanthin, lutein, Zeaxanthin, $\beta$ Cryptoxanthin (MishraTanmayee Das et al., 2012), (GlinosEvangelina et al., 2010).

\section{Pharmacological studies of Canna indica AIDS / HIV1-RT Inhibition}

Canna indica was one of medicinal plants used to treat AIDS tested for their HIV type 1 reverse transcriptase inhibitor activity. Canna indica rhizomes showed HIV-1 inhibition ratio higher than $90 \%$ at $200 \mathrm{bug} / \mathrm{ml}$ concentration. Further study of $C$. indica\& two proteins isolated showed significant HIV-1 RT inhibition (Srivastava, J. et al., 2010).

\section{Cannagenin / Molluscicidal}

(1) Study yielded cannagenin, which had a highly synergistic with chlorophyll on the morality of snails. (2) Study showed Canna indica to have time \& dose dependent mollusicidal activity in a dose that was not toxic for the fish Colisafasciatus, which shares the same habitat as the snail L acuminata (Sanchalika Mishra et al., 2013).

\section{Hepatoprotective}

(1) Study showed the methanol extract of aerial parts of Cannaindica has liver protective effect against carbon tetrachloride -induced hepatotoxicity. (2) Study of hydro-alcoholic extract showed significant antioxidant \& hepatoprotective activity. Results were compared with reference drug Silymarin (Yadunath M. Joshi et al., 2009).

\section{Cytotoxicity / Anticancer}

Study yielded two pure compounds, stigmasterol \& 6- beta- hydroxystigmasta-4, 22-diene-3-one \& two other toxic minor components. They showed cytotoxicity against P388 dfleukemia cells (WoradulayapinijWarunya et al., 2005).

\section{Antioxidant}

Study results clearly indicate the aerial parts of Canna indicaare effective in scavenging free radicals \& have the potential to be a powerful antioxidant (GlinosEvangelina et al., 2010).

\section{Flower Anthocyanins / Antioxidant / Pigment Source}

Study of red flowers of Canna indica isolated anthocyanins. Four anthocyanin pigments were isolated from quercetin\& lycopene. The compounds showed good antioxidant activity. Result suggest a promising pigment source for food applications (Mishra Tanmayee Das et al., 2012).

\section{Studies on antioxidants enzymes}

The efficient scavenging of hydrogen peroxide was performed by normal (control level) activities of both ascorbate peroxidase \& catalase in leaf \& increased activity of only catalase in root, preventing its accumulation at toxic concentration \& subsequent damage of membrane lipids by peroxidation. Together these ensured normal dry weight of leafs \& roots, indicating tolerance of Canna indica plant to copper induced oxidative stress (Yadunath M. Joshi et al., 2009).

\section{Surfactant-enhanced anaerobic acidogenesis of Canna indica $L$. by rumen cultures}

Polyoxy ethylene sorbitan monolate (Tween 80) was used to enhance the anaerobic acidogenesis of Canna indical by rumen culture. Dose of Tween 80 at $1 \mathrm{ml} / /$ enhanced the volatile fatty acids (VFA) production from the acidogenesis of Canna compared to the control. However, Tween 80 at higher dosages than $5 \mathrm{ml} / \mathrm{l}$ inhibited the rumen microbial activity and reduced the VFA yield. Response surface methodology was successfully used to optimize the VFA yield. A high VFA production was achieved from Canna pre-soaked with Tween 80, suggesting that the structure of Canna was disrupted by Tween 80 (SunanChainaku et al.,). 
Differential Activation of Glucose Transport in Cultured Muscle Cells by Polyphenolic Compounds from Canna indica $L$. Root

Effect of extract of a plant, which has been used as a traditional medicine for treating diabetes on glucose transport activity, was evaluated in cultured L8 muscle cells. The aqueous extract of Canna indica root $(\mathrm{Cl})$ at doses of $0.1-0.5 \mathrm{mg} / \mathrm{ml}$, which contains total phenolic compounds equivalent to $6-30 \mathrm{mg}$ of catechin caused a dose- \& time-dependent induction of 2-deoxy-[3H] glucose (2-DG) uptake activity. The induced 2-DG uptake was significantly increased within $8 \mathrm{~h}$ \& reached a maximum by $16 \mathrm{~h}$. The Canna indica extract increased the amount of glucose transporter isoform 1 (GLUT1) \& 4 (GLUT4) at the cell surface \& enhanced expression of GLUT1 protein (Talukdar, D. 2013).

\section{Antinociceptive and anthelmintic activity of Canna indica}

Dried, coarsely powdered leaves, flowers, rhizomes \&seeds of Canna indica were successively extracted with benzene \& methanol in Soxhlet apparatus. The effect of benzene \& methanol extracts of various parts of Canna indica on nociceptive response using writhing test \& hot plate method in mice was examined. All the extracts of Canna indica showed significant central \& peripheral analgesic activity in hot plate method \& acetic acid-induced writhing test, respectively, at the dose of $50 \mathrm{mg} / \mathrm{kg}(-1)$ intraperitoneally. Methanolic extracts of leaves of Canna indica showed highest increase in reaction time in hot plate method while benzene extract of leaves of Canna indica showed more inhibitory effect on writhing induced by acetic acid. Anthelmintic activity of these extracts was evaluated on Pheritimaposthuma. Results showed that the methanolic extract of rhizomes of the plant took less time to cause paralysis of the earthworms (YueZheng-Bo et al., 2008).

\section{Anti-inflammatory, analgesic and immunomodulatory effects}

The effect of Canna indica ethanolic extract (CIE) on productions of nitric oxide (NO), prostaglandin E2 (PGE2), and interleukin-1 $\beta$ (IL-1 $\beta$ ) in lipopolysaccharide (LPS)- induced RAW 264.7 macrophages was investigated. In addition, the effects of $\mathrm{CIE}$ in high glucose (HG)-induced U937 monocytes on m RNA expressions of IL-8 and monocytechemoattractant protein-1 (MCP-1), \& regulation of mitogen-activated protein kinase (MAPK) pathways were also identified. CIE was found to inhibit the production of inflammatory mediators including NO, IL-1 $\beta$, \&
PGE2 from LPS-induced RAW 264.7 macrophages. The increases in $\mathrm{HG}$-induced $\mathrm{m}$ RNA expressions of IL-8 \& MCP-1 were also significantly inhibited by CIE. Stimulation of HG in U937 monocytes resulted in activation of p38 MAPK, ERK1/2, \& JNK. However, CIE treatment significantly decreased phosphorylation of p38 MAPK, ERK1/2, \& JNK (Chen HJ et al., 2013). The effect of benzene \& methanol extracts of various parts of $C$. indica on nociceptive response using writhing test \& hot plate method in mice was examined. All the extracts of $C$. indica showed significant central \& peripheral analgesic activity in hot plate method \& acetic acid-induced writhing test respectively, at the dose of $50 \mathrm{mg} / \mathrm{kg}$ ip. Methanolic extract of leaves of $C$. indica showed highest increase in reaction time in hot plate method, while benzene extract of leaves of $C$. indica showed more inhibitory effect on writhing induced by acetic acid (Nirmal SA et al., 2007).

\section{Anti-diarrheal effect}

The anti-diarrheal effect of Canna indica methanolic extract was evaluated in castor oilinduced diarrhoea, charcoal meal transit \& acetylcholine-induced contractions of the isolated rat ileum models. In the castor oil induced diarrhoea, loperamide $(5 \mathrm{mg} / \mathrm{kg})$ $\& 50,100 \& 200 \mathrm{mg} / \mathrm{kg}$ of the extract were used \& compared with a control ( tween 80 ), while in the gastrointestinal transit, atropine (2.5 $\mathrm{mg} . \mathrm{kg}) \& 100 \& 200 \mathrm{mg} / \mathrm{kg}$ of the extract were used \& also compared with a control (tween 80 ). A dose of $10 \mathrm{mg} / \mathrm{ml}$ of the extract was used against acetylcholine induced contraction in the isolated ileum experiments. The extract of Canna indica was significantly $(p<0.050)$ reduced both the castor oil induced diarrhoea \& the charcoal plug transit time in a dose dependent manner. In the castor oil induced diarrhoea, the extract decreased the intraluminal fluid content in mice, with the highest reduction recorded at $200 \mathrm{mg} / \mathrm{kg}$ dose of the extract, though this was slightly better than that of loperamide. In the charcoal plug transit, both doses of the extract \& atropine were significantly $(p<0.05)$ decreased the distance travelled by the charcoal plug in the intestine of the mice, with the $200 \mathrm{mg} / \mathrm{kg}$ producing an inhibitory effect higher than that of atropine. The effect of $C$. indica on the isolated rat ileum showed that the extract produced significant $(\mathrm{p}<0.0001)$ inhibitory effect on acetylcholine induced contraction (Josephine $\mathrm{OO}$ et al., 2013).

\section{Hemostatic effect}

The hemostatic effect of Canna indica was evaluated in mice. The bleeding time (BT), 
clotting time (CT), \& the permeability of abdominal capillary were measured. The results showed that Canna indica significantly reduce the BT, CT \& the permeability of abdominal capillary (Lin ZL et al., 2011).

\section{Antibacterial and antiviral effects}

Methanolic extract of Canna indica leaves \& flowers showed antibacterial activity against $B$ subtilis. Ethyl acetate extract of flowers \& stems/barks also showed activity against b subtilis, while, hexane \& distilled water extracts of Canna indica leaves, flowers\& stems/barks showed no antibacterial activity (Abdullah $\mathrm{E}$ et al., 2012). The oil showed good antibacterial activity against Staphylococcus aureus but mild activity against Bacillus subtilis (Indrayan AK et al., 2011). A novel $10 \mathrm{kDa}$ protein with anti-HIV-1 reverse transcriptase (RT) inhibitory activity was isolated from leaves of Canna indica L (Thepouyporn A et al., 2012).

\section{Non - pharmacological studies on Canna plant}

Microbial community variation in phytoremediation of triazophos by Canna indica Linn. In a hydroponic system: Phytoremediation of triazophos $(\mathrm{O}, \mathrm{O}$ - diethylO-(1-phenyl-1, 2, 4-triazole-3-base) sulphur phosphate, TAP) pollution by Canna indica Linn. In a hydroponic system has been well studied, whereas the microbial mechanism on TPA degradation is still unknown. The variation in microbial community compositions was investigated by analysing phospholipid fatty acids (PLFAs) profiles in microbes under TAP exposure. The TAP exposure resulted in an increase in proportions of fatty acid 16:0 \& decrease in fatty acid $18 \mathrm{~L}: 2 \omega 9,12 \mathrm{c}$, indicating that TAP may stimulate the reproduction of microorganisms \& inhibit the growth of fungi to some degree. Significant correlation was found between the ratio of fungi to bacteria \& TAP removal $(r 2=0.840, p<0.01)$. In addition, the microbial community in the phytoremediation system with Canna indica was dominated by Gram negative bacteria, which possibly contributed to the degradation of TAP (Purintrapiban J. et al., 2006).

\section{Interactive effects of $N$ \& $P$ on growth but not on resource allocation of Canna indica in wetland microcosms}

The interactive effect of three levels of $N(m \mathrm{M})$ (low 0.36, medium 2.1 \& high 6.4) \& two levels of $P(\mathrm{~m} \mathrm{M})$ (low 0.10 \& high 0.48 ) on growth \& resource allocation of Canna indica Linn. were studied in wetland microcosms. After 91 days of plant growth, there was a significant interactive effect of $\mathrm{N} \& \mathrm{P}$ on plant growth, but not on resource allocation (except for allocation of $\mathrm{N}$ to leaves \& allocation of $\mathrm{P}$ to the stems). The plant growth positively responded to the relatively higher nutrient availability (taller plants with more stems, leaves \& flowers (Nirmal S. A. et al., 2007).

\section{Chemical fractionation \& translocation of heavy metals in Canna indica $L$. grown on industrial waste amended soil}

A pot experiment was carried out to assess the effect of different amendments of industrial sludge on the growth of Canna indica $L$. as well as the translocation potential of heavy metals of this plant. The accumulation of metals ( $\mathrm{Cr}, \mathrm{Fe}, \mathrm{Cd}, \mathrm{Cu}, \mathrm{Ni}, \mathrm{Zn}, \mathrm{Mn} \& \mathrm{~Pb})$ in different parts of Canna indica L. grown on industrial sludge-amended soil increased with time \& increasing doses of sludge amendments (Xiao Huiping et al., 2010).

\section{From salmon pink to blue natural sensitizers for solar cells: Canna indica $L$., Salvia splendens, cowberry \&Solanumnigrum $\mathbf{L}$.}

Study on dye-sensitized solar cells (DSSCs) with extracts of Canna indicaL, Salvia splendens, Solanumnigrum L. as sensitizers is firstly reported in this paper. DSSCs were assembled by using natural dyes extracted from Canna indica $L$, Salvia splendens, cowberry \& Solanumnigrum L. as sensitizers. The energy conversion efficiency of the cells sensitized with dyes of Canna indica L, Salvia splendens, cowberry \& Solanumnigrum L. was $0.29 \%, 0.26 \%, 0.13 \% \& 0.31 \%$, respectively. A novel technique was taken to fabricate Tio2 electrode films by electrophoresis. We present FTIR \& UV- vis spectroscopy studies of structures \& light absorption of these four kinds of natural dyes. The electrochemical impedance spectroscopy (EIS) was used to analyse the interface resistance of cells. The result indicated that high resistance existed in the interfaces of cell with cowberry extract as sensitizer (Zhang Zhenhua et al., 2008).

\section{Optimization of anaerobic acidogenesis of an aquatic plant, Canna indica $L$., by rumen cultures}

Anaerobic acid genesis of Canna indica $L$. (canna) by rumen cultures was investigated in this study. Fractional factorial design (FFD) was used to explore the roles of the growth factors such as substrate concentration \& $\mathrm{pH}$ in such a bioconversion, whereas response surface methodology (RSM) was employed for optimizing this acidogenic process. The optimum substrate concentration \& $\mathrm{pH}$ for the acidogenesis of Canna were found to be $8.2 \mathrm{~g}$ vs $1.1 \& 6.6$, respectively, \& the corresponding degradation efficiency of Canna was $52.3 \%$. 
Volatile fatty acid yield peaked at $0.362 \mathrm{~g}, 1$ VS degraded at a substrate concentration of $6.9 \mathrm{~g}$ vs $1,1 \& \mathrm{pH} 6.7$ (Bose Sutapa et al., 2008).

Nitrogen nutrition of Canna indica: Effects of ammonium versus nitrate on growth, biomass allocation, photosynthesis, nitrate reductase activity and Nitrogen uptake rates

The effects of inorganic nitrogen $(\mathrm{N})$ source (NH4+, NO3 - or both) on growth, biomass allocation, photosynthesis; $\mathrm{N}$ uptake rate, nitrate reductase activity \& mineral composition of Canna indica were studied in hydroponic culture. The relative growth rates (0.05-0.06 g), biomass allocation \& plant morphology of Canna indica were indifferent to nutrition (LuoPeihui et al., 2009).

\section{Phytoremediation of BTEX contaminated soil by Cannageneralis}

Bioaccumulation experiments showed that the Canna (Cannageneralis) could accumulate BTEX (benzene, toluene, ethyl benzene \& xylenes) from root zone \& rhizome zone soil \& translocate these compounds to the shoot. A comparison among the compounds showed that the sequences for accumulation in the root, rhizome \& shoot were strongly related to their physicochemical properties (i.e. Kow values \& molecular weight). For removal efficiency, the Canna could remove about $80 \%$ of BTEX in the root zone \& rhizome zone soilin 21 days. In addition the removal efficiency in BTEX contaminated soil with $40 \%$ water content was a little higher than that found with $20 \%$ soil water content. This result indicated that the soil water content should also be considered when phytor-emediation is employed (YueZheng-Bo et al., 2007).

\section{Removal of nutrients from waste water with Canna indica $L$. under different vertical flow constructed wetland conditions}

Constructed wetlands are becoming increasingly popular worldwide for removing contaminants from domestic waste water. This study investigated the removal efficiency of nitrogen $(N)$ \& phosphorus $(P)$ from waste water with the simulated vertical-flow constructed wetlands (VFCWs) under three different substrates (i.e., BFAS or blast furnace artificial slag, CBAS or coal burn artificial slag, \& MSAS or midsized sand artificial slag), hydraulic loading rates (i.e., 7,14, \&21 cmd-1), wetland operational periods $(0.5,1, \& 2$ years) as well as with \& without planting Canna indica L. (Konnerup Dennis et al., 2010).

Arabinoxylan from Canna edulisKer byproduct and its enzymatic activities

Arabinoxylan (AX) was extracted \& purified from Canna edulis Ker by-product. Through column chromatography, AX was further separated, leading to the isolation of two single compounds, namely, AXI \& AXII. Moreover, the structures of AXI \& AXII were characterized by GC, GC-MS \&NMR. The result indicated that arabinose \&glucuronic acid occurred at 1,4-linked xylose units as back bone at positions $3 \& 2$ in both AXI \& AXII with varying ratios, respectively. Furthermore, the effects of $A X$ on enzymatic digestibility of lactoglobulin\&tributyrin hydrolysis by lipase were evaluated. The results showed that $A X$ had obvious inhibition effects on pepsin \& lipase activities, \& decreased lactoglobulin digestibility \&tributyrin hydrolysis as well. It indicates that Canna edulisAX could be used as a functional food ingredient (Boonsaner M. et al., 2011).

\section{Pharmacological, Traditional and non-pharmacological Uses of Canna indica}

\begin{tabular}{|c|c|c|c|c|}
\hline $\begin{array}{l}\text { Sr. } \\
\text { No. }\end{array}$ & Plant part used & Traditional uses & Pharmacological uses & Non-pharmacological uses \\
\hline 1. & Rhizomes & $\begin{array}{c}\text { Decoction of fresh rhizome is used as jaundice } \\
\text { symptoms fevers, dropsy \& dyspepsia. } \\
\text { In the Philippines, decoction of rhizome used } \\
\text { as diuretic, antipyretic. } \\
\text { Macerated rhizomes are used to alleviate nose } \\
\text { bleeds. } \\
\text { In Thailand, rhizomes has been used with other } \\
\text { herbs for cancer treatment. } \\
\text { In Costa-rica infusion of rhizomes used as } \\
\text { emollient. } \\
\text { In Gabon the rhizomes is used in enemas } \\
\text { against dysentery \& intestinal worms } \\
\text { (Boonsaner M. et al., 2011), (CuiaLihua et al., } \\
2010 \text { ). } \\
\text { An aqueous decoction is taken in Congo by } \\
\text { women with irregular menses (Zhang Juan et } \\
\text { al., 2011). }\end{array}$ & $\begin{array}{c}\text { In vitro HIV type } 1 \\
\text { reverse transcriptase } \\
\text { inhibitor activities } \\
\text { (Srivastava J. et al., } \\
2010 \text { ). } \\
\text { Antimicrobial activity, } \\
\text { antioxidant activity. }\end{array}$ & $\begin{array}{l}\text { The rhizome of Cannas is rich } \\
\text { in starch, \& it has many uses } \\
\text { in agriculture. }\end{array}$ \\
\hline
\end{tabular}




\begin{tabular}{|c|c|c|c|c|}
\hline 2. & Leaves & $\begin{array}{l}\text { In Costa Rica infusion of leaves used as } \\
\text { diuretic. In southwest Nigeria, leaves used for } \\
\text { malaria (Konnerup Dennis et al., 2010). }\end{array}$ & $\begin{array}{l}\text { Used in malaria } \\
\text { (CuiaLihua et al., 2010). }\end{array}$ & $\begin{array}{l}\text { A fibre obtained from the } \\
\text { leaves is used for making } \\
\text { paper. Smoke from the } \\
\text { burning leaves is said to be } \\
\text { insecticidal (Walker \&Sillans } \\
\text { (1961). }\end{array}$ \\
\hline 3. & Flowers & $\begin{array}{c}\text { Decoction of flowers used for external wound } \\
\text { bleeding. }\end{array}$ & $\begin{array}{l}\text { The flower are said to } \\
\text { cure eye disease, } \\
\text { antioxidant activity, } \\
\text { antibacterial activity } \\
\text { (GlinosEvangelina et } \\
\text { al., 2010). }\end{array}$ & \\
\hline 4. & Whole plant & $\begin{array}{c}\text { In Bangladesh, paste of plant used for } \\
\text { tonsillitis. }\end{array}$ & $\begin{array}{l}\text { Aerial parts of Canna } \\
\text { indica shows } \\
\text { hepatoprotective } \\
\text { activity, antioxidant } \\
\text { activity (Mishra } \\
\text { Tanmayee Das et al., } \\
\text { 2012), } \\
\text { (GlinosEvangelina et } \\
\text { al., 2010). } \\
\end{array}$ & $\begin{array}{c}\text { In more remote regions of } \\
\text { India, Cannas are fermented } \\
\text { to produce alcohol. } \\
\text { The plant yields a fibre from } \\
\text { the stem. } \\
\text { Young shoots used as a } \\
\text { vegetable (Bouquet 1937). }\end{array}$ \\
\hline 5. & Root & $\begin{array}{c}\text { A decoction of the root with fermented rice is } \\
\text { used in the treatment of gonorrhoea \& } \\
\text { amenorrhoea. } \\
\text { The powdered root is taken in Nigeria as a cure } \\
\text { for diarrhoea \& dysentery (O Tolu. Dugbemi O } \\
\text { et al., 2007). } \\
\text { In India the root are recognized as diaphoretic } \\
\text { \& diuretic, diaphoretic, stimulant \& demulcent \& } \\
\text { are administered in fevers \& dropsy (Walker } \\
\text { 1953). }\end{array}$ & $\begin{array}{l}\text { Molluscicidal activity, } \\
\text { acrid \&stimulant. }\end{array}$ & $\begin{array}{c}\text { The roots are starchy. Starch } \\
\text { has been extracted in a small } \\
\text { way in Indochina. } \\
\text { They are eaten in Asia, \& have } \\
\text { been eaten in W Africa in time } \\
\text { of dearth entry. }\end{array}$ \\
\hline 6. & Seeds & Considered as cordial \& vulnerary. & & $\begin{array}{c}\text { The seeds used as beads in } \\
\text { jewellery also used in mobile } \\
\text { element. Musical instruments. } \\
\text { A purple dye is obtained from } \\
\text { the seed (Walker \&Sillans, } \\
\text { 1961), (Ainslie, 1937), (Sastri, } \\
\text { 1950). }\end{array}$ \\
\hline
\end{tabular}

\section{CONCLUSIONS}

In recent years, ethnobotanical and traditional uses of natural compounds, especially of plant origin received much attention as they are well tested for their efficacy \& generally believed to be safe for human use. They obviously deserve scrutiny on modern scientific lines such as phytochemical investigation, biological evaluation on experimental animal models, toxicity studies, investigation of molecular mechanism of action of isolated phytoprinciples \& their clinical trials. Very little effort of traditional \& folk claims has been made by researchers to explore the therapeutic potential of Cannaindica plant. It is interesting to note that Canna indica possessing a wide range of phytochemical almost in every part of it like flavonoids, tannins, alkaloids, starch etc. \& has been reported to posses various activity like anthelmintic activity, antibacterial activity, HIV type 1 reverse transcriptase inhibitor activity, antimicrobial activity, antioxidant activity, antifungal activity, molluscicidal activity, hepatoprotective activity. Since the global scenario is now changing towards the use of nontoxic plant product having traditional medicine use.

\section{BIBLIOGRAPHY}

1. Ainslie.

$1937 ; 69$

(http://plants.jstor.org/).

2. Al-Snafi AE. Bioactive components and pharmacological effects of Canna indica-an overview. Int J PharmacolToxicol. 2015;5:71-5.

3. Abdullah E, Raus R and Jamal PA. Extraction and evaluation of antibacterial activity from selected flowering plants. Am Med. J2012;3:2732.

4. Bouquet. 1969;78, as C. bidentataBertolini.

(http://plants.jstor.org).

5. Bose Sutapa, Jain Anshul, Rai Vivek and Ramanathan AL. Chemical fractionation and translocation of heavy metals in Canna indica L. grown on industrial waste amended soil Journal of Hazardous Materials. 2008;160:187-193. 
6. Boonsaner $M$, Borrirukwisitsak $S$, Boonsaner A. Phytoremediation of BTEX contaminated soil by Canna generalis Ecotoxicology and Environmental Safety. 2011;74:17001707.

7. Chate E. Le Canna, son histoire, sa culture. Libraire central d'Agricultureet de Jardinage. 1867.

8. Cooke and Ian. The Gardener's Guide to Growing Cannas, Timber Press. 2001. ISBN 0-88192-513-6.

9. CuiaLihua, Ouyangb Ying, LouaQian, YangcFengle, Chena Ying, Wenling Zhua and Shiming Luo Removal of nutrients from waste water with Canna indica L. under different vertical flow constructed wetland conditions Ecological Engineering. 2010;36:10831088.

10. De l'Ecluse and Charles. Histoire des plantes rare observes en Espagne. 1576.

11. Enrique J, Baran I, Ana C, GonzalezBarol, Maria M, Ciciarelli2, Cristina H and Rolleri2. Characterization of biominerals in species of Canna (Cannaceae). 2010.

12. Grootjen CJF. Bouman. 1988. Seed structure in Cannaceae.

13. Ghani A. Medicinal Plants of Bangladesh with chemical constituents \& uses. $2^{\text {nd }}$ edition Asiatic Society of Bangladesh, 2003, 5 oldSecretariateroad, Nimtali, Dhaka, Bangladesh.

14. Glinos Evangelina Cocucci AA. Pollination biology of Canna indica (Cannaceae) with particular reference to the functional morphology of the style Plant SystEvol. 2010.

15. Indrayan AK, Bhojak NK, Kumar N, Shatru A and Gaur A. Chemical composition \& Antimicrobial activity of the essential oil from rhizomes of Canna indica. Ind Jour chem. 2011; 50B;1136-1139.

16. Indira Priya Darsini A, Shamshad $S$ and John Paul M. Canna indica (L.): A Plant With Pontential Healing Powers. A Review. 2015;6(2):(B) 1-8.

17. Johnson's Gardeners Dictionary, 1856.

18. Jayakumari TR and Stephen. Princymol Morphological \& Anatomical Features of Queensland Arrowroot (Canna edulis Ker.) Journal of Root CroPprsi,n c2y0m0o91, SVtoelp. H3e5n 2;164-168.

19. Josephine OO, Josephine $O O$ and Cosmos OT. Evaluation of the antidiarrhoea activity of the methanolic extract of Canna indica leaf (Cannaceae). International Journal of Pharmaceutical \&Chemical Sciences. 2013;2(2):669-674.

20. Kessler JR. Canna Lilies for Alabama Gardens. Alabama Cooperative Extension System. Auburn, Alabama: A\&M University \& Auburn University Press. 2010;307-31.

21. Konnerup Dennis and Brix Hans. Nitrogen nutrition of Canna indica: Effect of ammonium versus nitrate on growth, biomass allocation, photosynthesis, nitrate reductase activity \& N uptake rates Aquatic Botany. 2010;92:142-148.

22. Lerman JC and Cigliano EM. New carbon-14 evidence for six hundred years old Cannacompacta seed. 1971.

23. LuoPeihui, NiuHaijun, Zheng Gang, BaiXuduo, Zhang Milin and Wang Wen. From salmon pink to blue natural sensitizers for solar cells: Canna indica L., Salvia splendens, cowberry \&Solanumnigrum SpectrochimicaActa Part A. 2009;74:936-942.

24. Lin ZL, Bai'e Z, Li H and Yun C. Hemostatic Effect of Canna indicaL. Journal of Dali University. 2011;10(12):24-26.

25. Mishra Tanmayee Das, Abhaya Prasad and Sen Arnab. Phytochemical Screening \& In-vitro Antioxidant Profiling of Solvent Fraction of Canna edulis Ker Gawler, Free Radicals \& Antioxidants. 2012; 2(1):13-20.

26. Maria de las Mercedes Ciciarelli Life Cycle in Natural Populations of Canna indica L. from Argentina. 101-114.

27. Mishra S, Yadav A and Singh SK. A review of Canna indica Linn:Pharmacognostic\&

pharmacological profile. $\mathrm{J}$ Harmon Res Pharm. 2013;2:131-44.

28. Nirmal SA, Shelke SM, Gagare PB, Jadhav PR and Dethe PM. Antinociceptive and anthelmintic activity of Canna indica. Natl Prod Res. 2007;21:1042-7.

29. Tolu O, Dugbemi O, Dunayo O, Akinsulire R, Aibinulbukun E and Fabeku Peter O. Medicinal Plants Useful for Malaria Therapy in Okeigbo, Ondo State, Southwest Nigeria Afr. J Trad CAM. 2007;4(2):191-198.

30. Pison., Histoire naturelle du Bresil. 1658.

31. Purintrapiban J, Suttajit $M$ and Forsberg NE. Differential Activation of 
Glucose Transport in Cultured Muscle Cells by Polyphenolic Compounds from Canna indica L. Root Biol. Pharm. Bull. 2006;29(10):1995-1998.

32. Sastri. orientalisRosc(http://plants.jstor.org). 1950;58.

33. Sunan-Chainaku. Study of Cytotoxicity of the Hexane crude extracted from the Rhizomes of Canna indica L. on Cancer cells IBIDS / International Bibliographic Information on Dietary Supplements.

34. Srivastava J and Vankar SP. Canna indica flower: New source of anthocyanins Plant Physiology \& Biochemistry. 2010;48:1015-1019.

35. Sanchalika Mishra, AshutoshYadav and Sandeep Kumar Singh. A Review on Canna indicaLinn:Pharmacognostic\&Pharmac ological Profile. 2013;2(2):131-144.

36. Tripathi SM and Singh DK. Molluscicidal activity of Punicagranatum bark \&Canna indica root, Brazilian Journal of Medical \& Biological Research. 2000;33:13511355.

37. Tanaka N. Taxonomic revision of the family Cannaceae in the New World and Asia Makinoa ser. 2001;2(1)::3443.

38. Thepouyporn A, Yoosook C, Chuakul W, Thirapanmethee K, Napaswad C and Wiwat C. Purification \& characterization of anti-HIV-1 protein from Canna indica leaves. Southeast Asian J Trop Med Public Health. 2012;43(5):1153-1160.

39. Talukdar D. Studies on Antioxidant Enzymes in Canna indicaPlant under Copper Stress. J Env Biology. 2013;34:93-98.

40. VanitaKanase and SunitaVishwakarma. Treatment of
Various Diseases By Canna indica-A Promising Herb. 2018;11(12):51-56.

41. Walker. 1953;A26.

42. Walker and Sillans. 1961:116(http://plants.jstor.org).

43. Woradulayapinij Warunya and Soonthornchareonnon Noppmas Chanpen. In vitro HIV type 1 reverse transcriptase inhibitory activities of Thai medicinal plants \&Canna indica L. Rhizomes Journal of Ethnopharmacology. 2005;101:84-89.

44. Xiao Huiping, Cheng Shuiping and Wu Zhenbin. Microbial community variation in phytoremediation of triazophos by Canna indica L. In a hydroponic system, Journal of Environmental Sciences. 2010;22(8):1225-1231.

45. Yun Zheng-Bo, Yu Han-Qing, $\mathrm{Hu} \mathrm{Hu}$ Zhen, Harada Hideki and You Yu Li. Surfactant-enhanced anaerobic acidogenesis of Canna indica L. by rumen cultures. Bioresource Technology. 2008;99:3418-3423.

46. Yadunath M VilasraoJodhi, Kadam J and Kaldhone Prashant R. Investigation of Hepatoprotective activity of Aerial Parts of Canna indica L. on carbon tetrachloride treated rats Journal of Pharmacy Research. 2009;2(11):1712-1715.

47. Zhang Zhenhua, Rengel Zed and Meney Kathy. Interactive effects of $\mathrm{N}$ \& $P$ on growth but not on resource allocation of Canna indica in wetland microcosms Aquatic Botany. 2008;89:317-323.

48. Zhang Juan and Wu Zheng Wang. Arabinoxylan from Canna edulis Ker by-product and its enzymatic activities Carbohdrate Polymers. 2011;84:656661. 